\title{
Studies of Tiger Beetles. CLXXVIII. A new Lophyra (Lophyra) from Somaliland (Coleoptera, Cicindelidae)
}

\author{
Fabio Cassola
}

Via F. Tomassucci 12/20, I-00144 Roma, Italy

urn:lsid:zoobank.org:author:AEA70AB7-0315-4166-8C90-41145C386A8C

Corresponding author: Fabio Cassola (fabiocassola@alice.it)

Academic editor:Achille Casale | Received 28 October 2008 | Accepted 9 December 2008 | Published 17 December 2008

urn:lsid:zoobank.org:pub:791F8D67-6BFF-44C0-9C28-AC9EFD48F72D

Citation: Cassola F (2008) Studies of Tiger Beetles. CLXXVIII. A new Lophyra (Lophyra) from Somaliland (Coleoptera, Cicindelidae). ZooKeys 4: 65-69. doi: 10.3897/zookeys.4.57

\begin{abstract}
A new tiger beetle species, Lophyra (Lophyra) praetermissa n. sp. (Coleoptera, Cicindelidae), obviously a close relative of $L$. (L.) histrio (Tschitschérine, 1903), is described from the environs of Erigavo, Somaliland (northern Somalia). Its discovery thus brings to 73 the number of the species of this genus presently known worldwide (39 species of which - 29 from Africa - belong to the typonominal subgenus).
\end{abstract}

\section{Keywords}

Tiger Beetles, Cicindelidae, Lophyra, Somaliland

\section{Introduction}

From 28 May to 11 June 2005 John Miskell and the author visited Somaliland (northern Somalia) where they collected eight tiger beetle species [Prothyma (Prothyma) bottegoi (W. Horn, 1897); Calomera alboguttata (Klug, 1832); Calomera aulica (Dejean, 1831); Lophyra (Lophyrina) latelimbata (Müller, 1941); Chaetodera regalis (Dejean, 1831); Chaetodera blanchardi (Fairmaire, 1882); Myriochila (Myriochila) melancholica (Fabricius, 1798); Myriochila (Monelica) hauseri (W. Horn, 1898); Hypaetha singularis (Chaudoir, 1876)], and a previously undescribed Lophyra (Lophyra) species, in the environs of Erigavo (Cassola and Miskell 1990), which is described herein. The genus

Copyright Fabio Cassola. This is an open access article distributed under the terms of the Creative Commons Attribution License, which permits unrestricted use, distribution, and reproduction in any medium, provided the original author and source are credited. 
Lophyra (Motschulsky 1859, 1861), which was subdivided in a few subgenera by Rivalier (1948, 1950, 1957, 1961), Cassola (1977) and Matalin and Cherkasov (2004), is mostly characterized by a peculiar ear-like shaped inner sac of the aedeagus.

\section{Lophyra (Lophyra) praetermissa Cassola, n. sp. (Fig. 1)} urn:lsid:zoobank.org:act:E408CEE7-9545-46C1-856B-C42742F72C56

Material examined. Holotype, $\hat{\sigma}$, and one paratype,,+ , from Somaliland (northern Somalia), Al Afweyn-Erigavo, $3.4 \mathrm{~km} \mathrm{~S}$ of Erigavo (10³5.9N, $\left.47^{\circ} 21.1 \mathrm{E}\right), 1800 \mathrm{~m}, 4$ June 2005, F. Cassola leg., in author's collection (FCC).

Diagnosis. A small Lophyra (Lophyra) species, especially resembling L. (L.) histrio (Tschitschérine, 1903), with all the elytral markings confluent with each other. A continuous wide marginal band from the shoulder to the elytral apex, connected with the anterior juxta-sutural spot (and sometimes to the second one as well) via a continuous scutellar band below the base. Humeral lunule emitting on disc a wide, rounded, transversal spur; middle band slightly elbowed on disc; apical lunule wide, slightly advanced in front along the suture. Second juxta-sutural spot elongated, pointing backwards near the suture. Labrum testaceous, wide and rounded in both sexes, slightly toothed in front, with four setae or setigerous punctures near forward margins (two in the middle, two at the lateral sides). Head, including genae, glabrous, with a fan of white recumbent hairs behind the eyes. Ground colour of head, pronotum and elytra slightly cupreous. Antennomeres 1-4 metallic dark-cupreous; antennomeres 5-11 yellowish, a bit darkened; antennomere 4 without any penicillum (Cassola 1983).

Description. Head dark bronze with cupreous reflections, finely striated on frons and vertex, a few stronger and longitudinal striae on the declivities of eyes; surface glabrous, a fan of white recumbent hairs behind each eye. Genae glabrous. Two setigerous punctures near the orbital margins at fixed loci. Labrum testaceous, large, roundish in both sexes, feebly tridentate in front, with four setae or setigerous punctures near forward margins (two in the middle, two at the lateral sides). Mandibles shiny piceous-black, shortly testaceous on basal outer sides. Maxillary and labial palpi testaceous with the last joint metallic greenish-black. Antennae as long as to the first third of the elytral length, a bit shorter in female; scape and antennomeres 2-4 metallic dark-cupreous; antennomeres 5-11 yellowish, a bit darkened; antennomere 4 of male without any penicillum (Cassola 1983).

Thorax: pronotum wider than long, of the same colour as the head, finely and evenly sculpted. Anterior and posterior grooves well-marked. Surface covered with a number of recumbent white hairs especially on the lateral sides. Notopleural sutures well-marked, proepisterna reddish-violet, mostly glabrous with long white recumbent hairs near the anterior margin and the coxae. Mesepisterna also partially setose; mesepimera and metepisterna covered with white recumbent pubescence. Coupling sulci poorly developed, consisting of a shallow puncture in the upper corners of the female mesepisterna. 


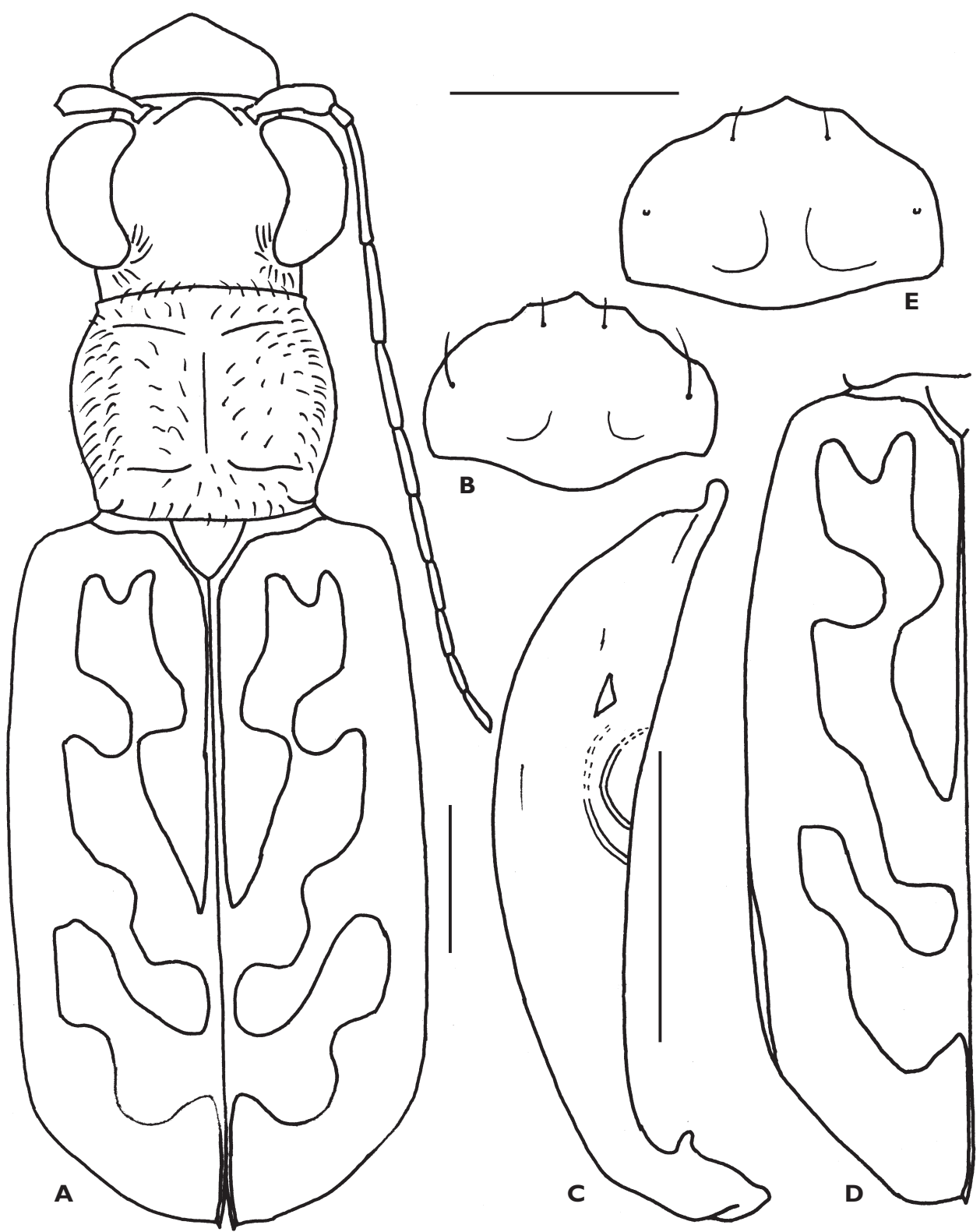

Fig. I. Lophyra (Lophyra) praetermissa n. sp., holotype, $\widehat{\partial}$, from $3.4 \mathrm{~km} \mathrm{~S}$ of Erigavo, northern Somalia (Somaliland): A. habitus, B. labrum, C. aedeagus; paratype, ㅇ, from same locality: D. left elytron, E. labrum.

Elytra: Elytral ground colour bronze with cupreous reflections, covered with small, evenly spaced, bluish punctures. All elytral markings confluent with each other, forming a continuous wide marginal band from the shoulder to the elytral apex, this band being connected with the anterior juxta-sutural spot (and narrowly to the second one 
as well) through a continuous scutellar band below the base. Humeral lunule emitting on disc a wide, rounded, transversal spur; middle band slightly elbowed on disc; apical lunule wide, shortly extending forward along the suture. Second juxta-sutural spot elongated, pointing behind near the suture. Elytra rounded at apex, with a small sutural tooth in both sexes.

Underside bronze with cupreous reflections. Sides of sternum, coxae and abdominal sternites more or less pubescent. Trochanters piceous-black. Legs dark-bronze to black, with cupreous reflections especially on "knees" and tibiae.

Length: 8-9 mm (without labrum).

Etymology. The name of this new Lophyra species refers to the fact that it was at first overlooked and mixed with Lophyra (Lophyrina) latelimbata (Müller, 1941), a species similar in size.

Remarks. The shape of the male aedeagus, with a triangular preapical tooth on the left side only and a rounded, slightly directed upwards apex, clearly places this new species in the group of Lophyra (Lophyra) neglecta Dejean, 1825 (Rivalier 1948; Rivalier 1950), however, the much smaller size and the different elytral markings easily help to distinguish it. The distinct elytral markings also distinguish $L$. $(L$.) praetermissa n. sp. from both the similarly sized species $L$. (L.) cassoliana Werner, 1997, from Tanzania (which, however, is slightly larger and has a reddish general ground colour), and L. (Lophyrina) latelimbata (Müller, 1941), from Somalia and Ethiopia, (which has different elytral markings and exhibits a distinct inner sac of aedeagus) (Cassola 1977). This new species looks like a small $L$. (L.) histrio, described from north-eastern Iran (Tschitchérine 1903) and also recently recorded from the Arabian peninsula (Wiesner 1993; Cassola and Rihane 1996; Cassola and Schneider 1997). These two species are likely closely related and distinguished by the large, roundish labrum and the smaller size of the new species. This discovery of an additional Lophyra species in Somaliland (northern Somalia) brings to 73 the number of the species of this genus presently known worldwide (39 species of which - 29 from Africa - belong to the typonominal subgenus).

\section{Key to the similar species}

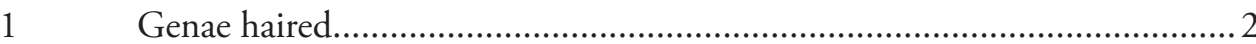

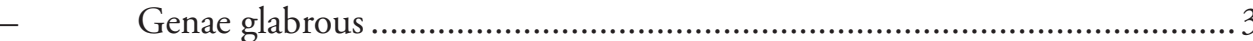

2 Fourth male antennomere devoid of penicillum (Tanzania) cassoliana Werner, 1997

- $\quad$ Fourth male anntenomere with a penicillum (Somalia, Ethiopia) latelimbata Müller, 1941 Body size larger than $10 \mathrm{~mm}$ (Iran, Arabian Gulf area, Oman) histrio Tschitschérine, 1903

- $\quad$ Body size smaller than $10 \mathrm{~mm}$ (Somaliland) .... praetermissa Cassola, sp. nov. 


\section{References}

Cassola F (1977) Studi sui Cicindelidi. XVII. Lophyra (Lophyrina nov.) latelimbata (Müller, 1941), nova comb. (Coleoptera Cicindelidae). Atti della Società italiana di Scienze naturali e Museo civico di Storia naturale di Milano 118: 402-406.

Cassola F (1983) Studi sui Cicindelidi. XXVIII. Osservazioni preliminari sopra una struttura sessuale maschile non genitale di alcune specie di Cicindelidi (Coleoptera Cicindelidae). Atti XII Congresso Nazionale Italiano di Entomologia 2: 93-103.

Cassola F, Miskell JE (1990) Somalian Tiger Beetles: faunistics and biogeography (Coleoptera, Cicindelidae). Biogeographia 14 (1988): 175-277.

Cassola F, Rihane A (1996) Notes on the Tiger Beetle Fauna of the Sultanate of Oman (Coleoptera, Cicindelidae). Fauna of Saudi Arabia 15: 196-205.

Cassola F., Schneider W (1997) Tiger Beetles (Coleoptera, Cicindelidae) from the Saudi Arabian Gulf coast. Fauna of Saudi Arabia 16: 247-253.

Matalin AV, Cherkasov SI (2004) A new subgenus and a new species of Lophyra from Vietnam (Coleoptera : Carabidae : Cicindelinae). Russian entomological Journal 13: 3-12.

Motschulsky V (1859) Insectes des Indes orientales, et de contrées analogues. 2de série. Etudes Entomologiques, 8: 1-187.

Motschulsky V (1861) Essai d'un catalogue des insectes de l'ile Ceylan. Bulletin de la Société Impériale des Naturalistes de Moscou, 34: 95-155.

Müller G (1941) Nuovi Coleotteri dell'Africa Orientale. Atti del Museo civico di Storia naturale di Trieste, 14 (23): 319-352.

Rivalier E (1948) Les Cicindèles du genre Lophyra (Motschoulsky). Revue Française d'Entomologie 15: 51-74.

Rivalier E (1950) Démembrement du genre Cicindela Linné (Travail préliminaire limité à la Faune Paléarctique). Revue Française d'Entomologie 17: 217-244.

Rivalier E (1957) Démembrement du genre Cicindela L. - III. Faune africano-malgache. Revue Française d'Entomologie 24: 312-342.

Rivalier E (1961) Démembrement du genre Cicindela L. (suite). IV. Faune Indo-malaise. Revue Française d'Entomologie 28: 121-149.

Tschitchérine T (1903) Mémoire sur les Cicindelidae des voyages de N. Zarudny dans la Perse orientale. Horae Societatis Entomologicae Rossicae 36: 1-21.

Werner K (1997) Lophyra (s. str.) cassoliana sp. n. from Tanzania (Coleoptera, Cicindelidae). Entomologia Africana 2: 17-19.

Wiesner J (1993) Über die Cicindelidae (Coleoptera) der Vereinigten Arabischen Emirate. Entomologische Zeitschrift mit Insektenbörse 103: 249-260. 